\title{
Exploring the Ethnic Immigrant Inflows from Latin America to Canada: 1981-2016 ${ }^{1}$
}

Fernando Mata

School of Sociological and Anthropological Studies

University of Ottawa

January 30, 2019

fmata@uottawa.ca

KEYWORDS: Latin America, Ethnicity, Immigration, Canada

\section{ABSTRACT}

Using 2016 census data, the study carried out five socio-demographic explorations regarding 25 ethnic immigrant inflows from Latin America to Canada occurring between 1981 and 2016. The population represented by these inflows comprised approximately 470 thousand immigrants. The data was drawn from two special 2016 census tables which collected information on immigrants' admission categories (economic, family and refugee) and their reported ethnic ancestries. Explorations focused on the following aspects: census counts and periods of arrival, residential preferences, admission class mix, population configurations and human capital attainment profiles. Five main historical immigrant waves had been already been identified by Canadian scholars: Lead or Eurolatino, Andean, Coup, Central American and Technological or Professional. Evidence of the presence of these immigrant waves was found in the census data explorations undertaken. Census figures revealed that the largest ethnic immigrant inflow corresponded to those reporting Spanish ancestry (158 thousand or 34\% of the total) followed by the Colombian, Mexican, Salvadoran and Peruvian inflows. Residential concentrations in the provinces of Ontario and Quebec were also detected. Explorations suggest that "Latino" communities in Canada are emerging as the demographic product of a mixture of admission classes which are uniquely distributed in age-gender cohorts of their respective population configurations. Human capital attainment explorations revealed that inflow members of the working populations corresponding to the fifth technological or professional wave from countries such as Venezuela, Mexico, Brazil and Colombia ranked at top levels of education and income achievements, those admitted as economic class in particular. The study of Latin American ethnic inflows to Canada is especially relevant for social policy because it represents a "collective" case study where the researcher is able to summarize a complex immigration picture through the examination of geographical region representing a sample of units which ensures maximum variation in terms of several push-pull migratory factors at work.

\footnotetext{
I Paper to be presented to the CISAN-UNAM conference, Mexico City, June 15-2021. The author would like to thank Jennifer Dumoulin and the Census Division of Statistics Canada for making available the data and their valuable support and guidance.
} 


\subsection{INTRODUCTION}

Canada is a multicultural society whose ethno-cultural composition has been shaped by multiple waves of immigrants and their descendants. Each annual inflow of new immigrants adds new members to the ethnic minorities already present in the country. Ethnic groups comprise individuals bound by linguistic and cultural practices through which a sense of collective identity is "produced and transmitted" from generation to generation (Cohen and Bains, 1988; Wallbeck, 2002). Immigrant inflows change the demographic configurations of ethnic groups and shape their institutional fabric, networks and community life (Belanger and Dumas, 1998; Kelly, 2003; Trovato, 2009, Carrière et.al, 2016).

Recent census statistics reveal a rising number of individuals in Canada reporting ethnic backgrounds tied to Latin America and the Hispanic cultural and linguistic heritage. In 2016, the total census counts for all those who reported Spanish and various Latin American ethnic backgrounds either as single or multiple origins totaled 463.4 thousand and 373.8 thousand respectively. Between the 2006 and 2016 censuses, these two ethnic subpopulations experienced an increase in the order of $21 \%$ and $34 \%$ respectively. One of the major factors contributing to the growth of the "Latino" population in Canada is a steady immigration of individuals from a wide spectrum of countries who are admitted to the country under three major admission classes: economic, family and refugee class. These classes respond to the major drivers stated by the immigration policy in Canada: the promotion of economic growth, facilitation of family reunification and humanitarian-related obligations ${ }^{2}$.

Latin Americans are arriving in Canada not only to escape violence but also in search of economic opportunities and social mobility (Simmons, 1993). The current socio-political and economic conditions in the Latin American region are described today as a period of "uncertainty and change" (ECLAC, 2019). Economic and ecological crisis, rising social conflict, political mobilization and socioeconomic restructuring are social forces which are struggling to take over the direction of social change. The recent popular upheavals in Venezuela, Chile, Bolivia and Ecuador illustrate this struggle which is characterized by a clash between polarized political models of social development. Immigrant waves from Latin America to Canada have risen or fallen as a consequence of the strength/weakness of migratory push-pull factors and the immigration policy developed in response to them. Piché (20112) argues that this Canadian policy is now being developed in the international context of the Trump era of "Reja-Muro" and is progressively moving towards a more "utilitarian"

\footnotetext{
2 The economic class comprises of individuals such as skilled workers, business immigrants and/or sponsored dependents of skilled dependents. The first two are selected via a point system, which assigns scores based on level of education, work experience, skills relevant for work in preferred occupations and knowledge of a Charter language. The family category comprises immigrants with immediate family members already living in Canada and are required to have a sponsor (typically the family member) who has agreed to provide financial support for a period of three to ten years following arrival. The refugee category comprises three types of refugees (state sponsored, privately sponsored and asylum).
} 
approach benefiting economic type of migration rather than social or humanitarian ones (temporary workers and/or entry of highly qualified permanent residents). In the case of low educated temporary workers, their legal status soon transforms itself into a "precarious" one which is often generated by the same immigration programs that admitted them to the country (see Bernhard, Landolt and Goldring, 2009).

Chart 1: Interpretative Diagram: Immigrant Waves from Latin America to Canada* and their most representative countries of origin

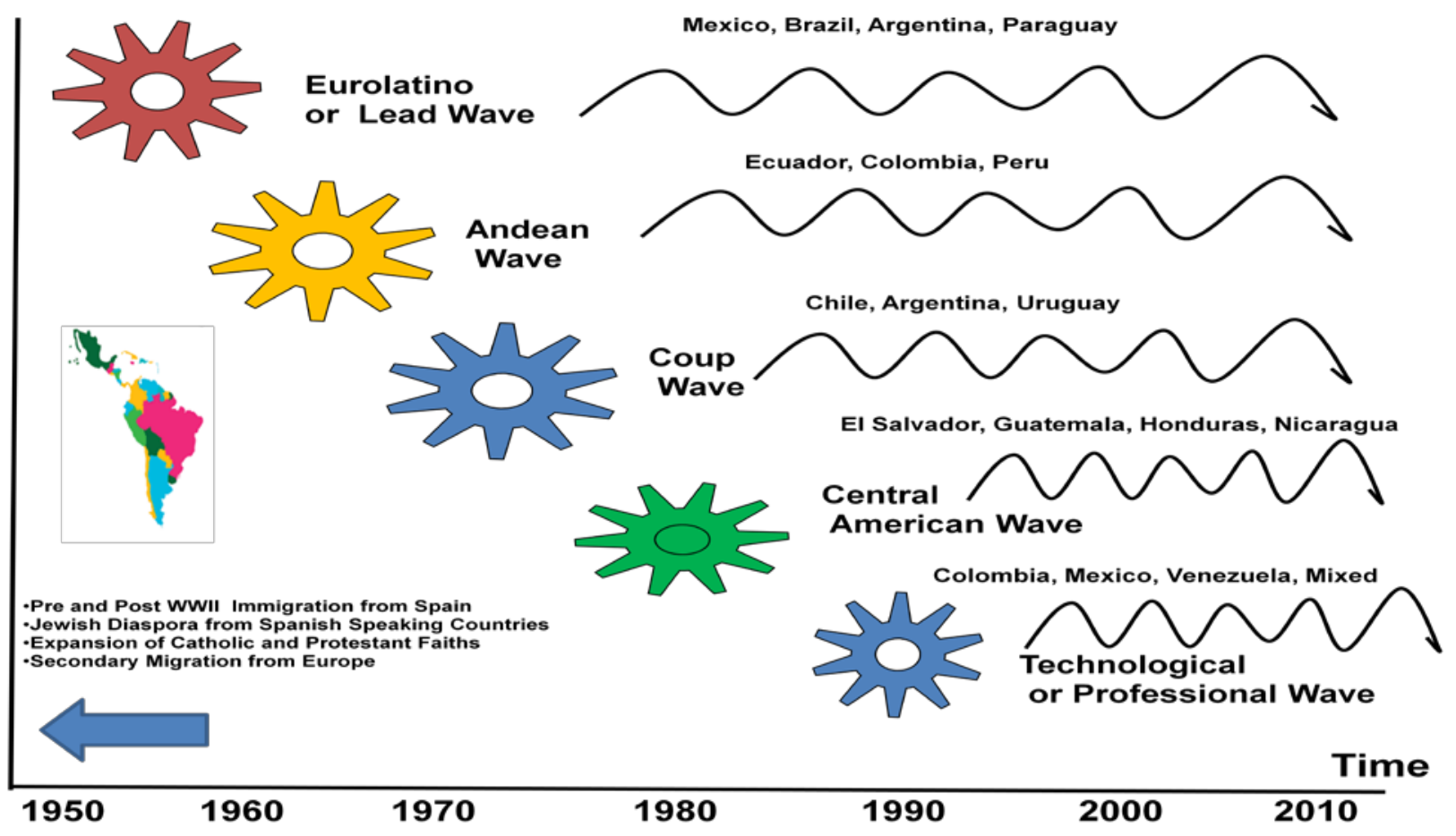

According to Canadian immigration statistics, about 2.5 million permanent residents were admitted to Canada between 2007 and 2016 (IRCC, 2017). Colombia, Mexico, Brazil and Venezuela topped the list of citizenship countries from the Latin American region (39.8, 36.3, 19.2 and 12.2 thousand individuals). As push-related factors have become stronger, the number of refugee claimants from Latin America has substantially increased over the years. During 2003-2012, the number of refugee claimants from Mexico and Colombia totaled approximately 37.5 and 17.5 thousand. Other major citizenship countries of claimants were El Salvador, Honduras, Guatemala and Cuba (CIC, 2014). Canadian scholars have conceptualized Latin American immigration to Canada as the product of five major immigrant waves which have reproduced themselves and taken various forms over time (Mata 1985; Garay, 2000; Veronis, 2010; Landolt, Bernhard and Goldring, 2011). Chart 1 shows an interpretative diagram of the wave typology proposed to explain the phenomenon. Through the process of "cumulative" causation, immigrant waves are presently undergoing a process of greater gender, multi-national, geographical and social class differentiation (Massey et. al., 1993; Castles et. al, 2009). 
The initial stages of "Latino" ethnic community formation may be traced back to immigration from Spain during the pre-and post-Franco days of the WWII period, the Jewish Diaspora of Spanish speakers, the expansion of Catholic and Protestant faiths and a secondary migration coming from Europe. The first major immigrant wave, the Eurolatino or Lead wave, occurred during the 1960s. This wave brought thousands of individuals of European background from countries such as Mexico, Brazil, Argentina and Paraguay to work in Quebec, Ontario and the Prairie provinces. Following a brief period of immigration amnesty in 1973 and economic "downturns" affecting the region, the second Andean wave (e.g. Ecuador, Colombia and Peru) was formed and lasted throughout the 1970s. Push-related factors later triggered two major refugee waves in the early and mid-1970s and 1980s. Military coups brought thousands of highly educated immigrants from Southern Cone countries such as Chile, Argentina and Uruguay while the Central American Civil War drew a wide spectrum of urban and rural workers from countries such as El Salvador, Guatemala and Nicaragua. At present, Canada is witnessing the unfolding of the fifth technological or professional wave consisting of highly skilled individuals occupationally drawn from the STEM industries ${ }^{3}$ coming from countries such as Colombia, Mexico and Venezuela (Landolt, Bernhard and Goldring, 2011). The personal experiences of members of the fifth wave have been eloquently described in the work carried out by Brito (2019) and Hernández-Ramírez (2019).

According to the 2016 Canadian Census, an ethnic immigrant inflow is defined as all immigrant admissions (i.e. as temporary residents) of individuals who share and report the same ethnic and/or cultural backgrounds. A systematic study of the social demography of Latin American ethnic immigrant inflows to Canada is especially relevant to Canadian immigrant policy because it constitutes an ideal "collective" case study (Creswell, 2007). Following this methodology, the researcher summarizes a complex immigration picture by selecting a representative sample drawn from a single geographic region that contains a heterogeneous population of units which ensures maximum variation in terms of the central phenomenon under study (e.g. the push-pull migratory factors at work).

There are several key research questions that come to mind when examining the ethnic immigrant inflows from Latin America arriving in Canada in the last decades prior to the 2016 Census . For instance what is the general picture in terms of reported ethnic origins, period of arrivals and residential preferences? What is the refugee mix present in these inflows and how does it impact the population configurations of inflows? When it comes to the human capital brought by workforce members, what trends or patterns are observed? Drawing on 2016 census data this paper addresses these broad research questions by undertaking five major socio-demographic data explorations which covered the following socio-demographic aspects: 1) Census Counts and Periods of Arrival, 2) Residential Preferences, 3) Admission Class Mix, 4) Population Configurations and 5) Human

\footnotetext{
${ }^{3}$ Science, technology, engineering and mathematics.
} 
Capital Attainment Profiles. The explorations are expected to provide important clues about the factors underlying ethnic community formation, selection criteria, human and social capital accumulation and current integration challenges faced by members of the "Latino" ethnic communities of Canada.

\subsection{ETHNIC IMMIGRANT INFLOW SAMPLE}

The 2016 Census of Canada provides researchers with a unique opportunity to undertake a "retrospective" look at Latin American immigration to Canada complementing those provided by annual immigration statistics ${ }^{4}$. The data sources used for the data explorations were two special custom tables (EO2695 and EO2860) which covered thirty five years of immigration: 1981 to 2016, time interval which taps into the pre and post-phases of the implementation of the 1992 Immigration and Refugee Protection Act (IRPA) ${ }^{5}$. The tables contained information on 216 ethnic ancestries which were defined as the ethnic or cultural origins of the person's ancestors where the latter are persons usually more distant than grandparents. The ethnic ancestry information was collected from the long-form census questionnaire which sampled $25 \%$ of Canadian households. For this analysis, 25 ethnic origins of immigrants were selected to represent a broad spectrum of Latin American identity markers including linguistic, national and Aboriginal ancestry identifications. The ancestries selected were as follows: 1) Aboriginal from Central \& South America, 2) Arawak, 3) Argentinian, 4) Brazilian, 5) Bolivian, 6) Chilean, 7) Colombian, 8) Costa Rican, 9) Cuban, 10) Dominican, 11) Ecuadorian, 12) Guatemalan, 13) Hispanic, 14) Honduran, 15) Maya, 16) Mexican, 17) Nicaraguan, 18) Panamanian, 19) Paraguayan, 20) Peruvian, 21) Puerto Rican, 22) Salvadoran, 23) Spanish, 24) Uruguayan and 25) Venezuelan.

\subsection{DATA EXPLORATIONS}

\section{Exploration 1: Census Counts and Arrival Periods}

The first broad exploration looked at the census counts and period of arrival of ethnic inflow members. According to the 2016 Census, the total population represented by the 25 Latin American ethnic inflows represented approximately 470.2 thousand individuals. This figure is relatively small compared to the largest inflows such as those corresponding to the Chinese, East Indian and Filipino ethnic ancestries (907.8 thousand, 706.7 thousand and 539.9 thousand respectively).

In terms of ancestry identification, the individual counts of ethnic immigrant inflows reflected both the prevalence of the two major Latin American ancestries reported in Canada (Spanish and Latin American) and the historical traces of the five major immigrant waves identified by

4 In the 2016 Census, characteristics such as the ethnic ancestry and the year of obtaining the landed immigrant status were systematically linked to their three admission class categories (economic, family and refugee). These refer to the immigration program or group of programs under which an immigrant was granted for the first time the right to live in Canada permanently by immigration authorities.

5 The Immigrant and Refugee Protection Act (IRPA) is an Act of the Parliament of Canada, passed in 2001, which replaced the Immigration Act of 1976 as the primary federal legislation regulating immigration to Canada. 
Canadian scholars. Counts of inflow members are presented in Chart 2. The Spanish ethnic ancestry identification topped the Latin American inflow counts: 158.3 thousand individuals (one third or $34 \%$ of the 25 inflow total). The second and third largest corresponded to the Colombian and Mexican ancestries with 63.0 thousand and 54.4 thousand individuals respectively (14\% and $12 \%$ of the total). Immigrants claiming Salvadoran and/or Peruvians ancestries accounted for $7 \%$ and $5 \%$ of the total while ethnic ancestries followed by Brazilian, Cuban, Venezuelan and Chilean ancestries. The gender ratio of inflows (females per 100 males) calculated was 111 showing females to be more participatory than males. Inflows with greater presence of women were those corresponding to the Peruvian, Ecuadorian, Venezuelan and Brazilian (129, 126, 120 and 119 females per 100 males respectively) inflows.

Chart 2: Population Counts (in thousands) of 25 Ethnic Immigrant Inflows* from Latin America to Canada, 1981-2016

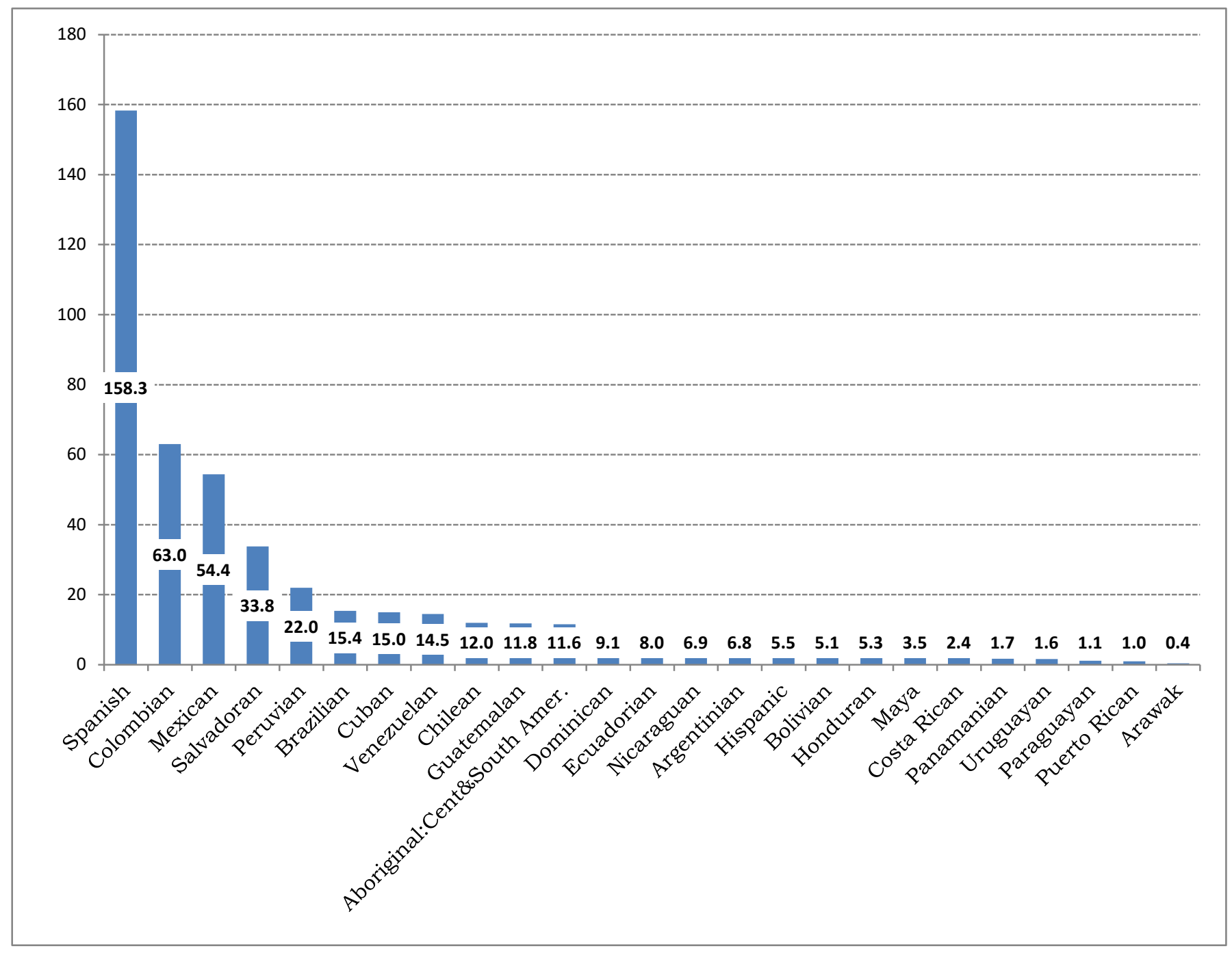

${ }^{*}$ Comprises single and multiple ethnic origins. Source: Custom Tabulation EO2695, 2016 Census of Canada 
Chart 3: Period of Arrival of Latin American Ethnic Inflows to Canada* 1981-2016

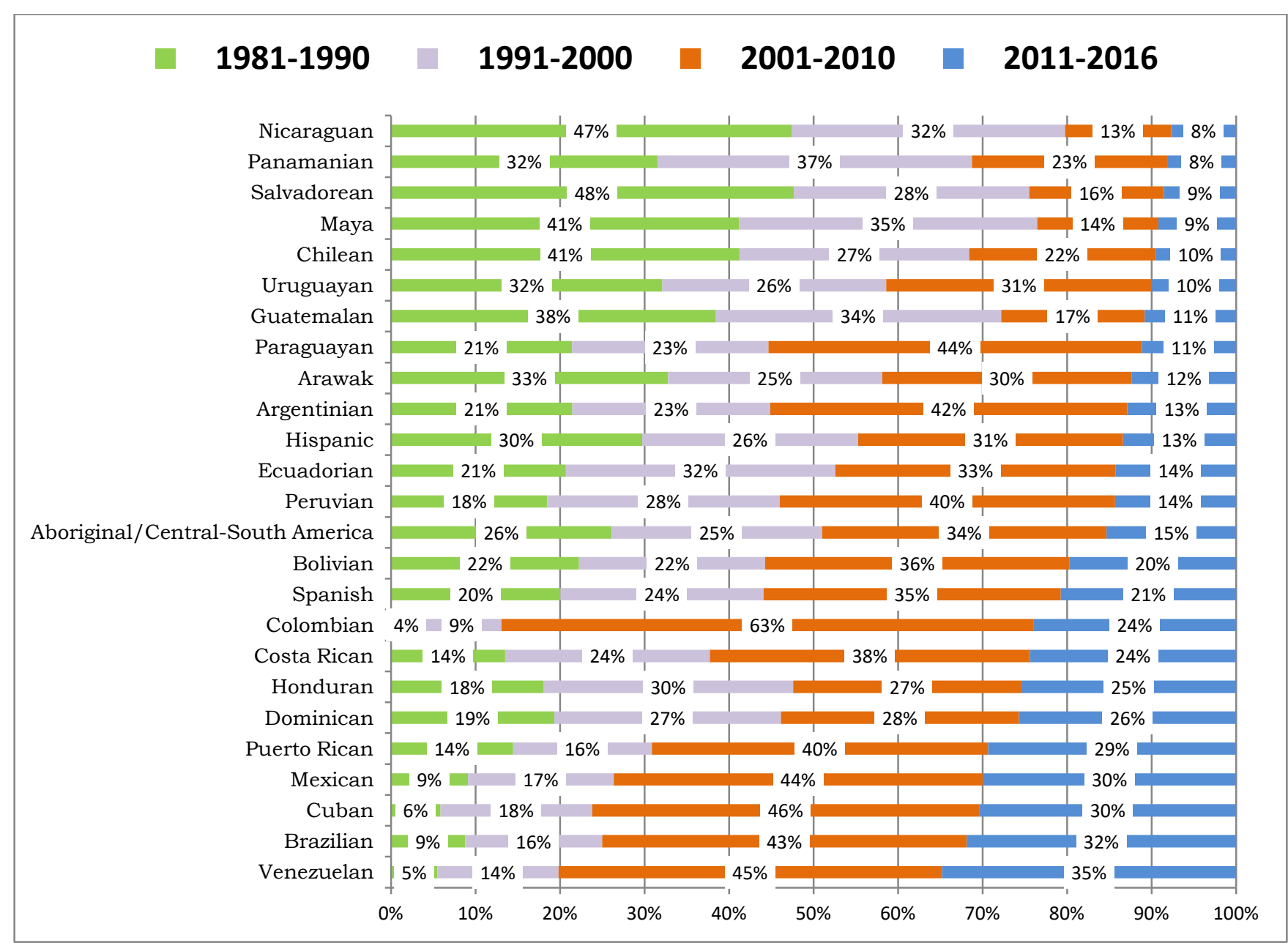

*Comprises single and multiple ethnic origins. Source: Custom Tabulations EO2695, 2016 Census of Canada

About one third of all members of Latin American inflow members (33\%) had arrived in Canada between 2001 and 2010 (see chart 3). About a third or more of immigrants reporting Venezuelan, Brazilian, Cuban and Mexican ancestries arrived between 2011 and 2016. These immigrants are part of the "technological" fifth immigrant wave described by scholars mostly comprising highly educated manpower drawn from the technology, service and industrial sectors of the Latin American region. On the other side of the spectrum, the older arrival cohorts corresponded to immigrants reporting ethnic origins such as Nicaraguan, Salvadoran and Maya. These are representative of fourth wave of Central American immigrants. Close to half of the Nicaraguan and Salvadoran ethnic inflows (47\% and 48\% respectively) came to Canada between 1981 and 1990. In the case of Chilean and Uruguayan inflows, these percentages were as high as $41 \%$ and $32 \%$. In the case of the larger Spanish ancestry immigrant inflow, more than a third of members (35\%) arrived between 2001 and 2010. The case of the Colombian inflow is of interest as Colombians were important constituents of the post-amnesty "Andean" wave of the 1970s as well as the most recent "technological" immigrant wave triggered in the mid-1990s. The majority (63\%) of 
individuals reporting Colombian ethnic ancestries had arrived in Canada between 2001 and 2010 while only $13 \%$ came before this particular period.

\section{Exploration 2: Residential Preferences}

The second exploration focused on the residential preferences of ethnic inflow members. Chart 4 presents the regional residences of Latin American ethnic immigrant inflow members at the time of the 2016 Census. On average, 46\% resided in the province of Ontario where the Metropolitan Toronto $\mathrm{CMA}^{6}$ s geographically situated.

Chart 4: Provincial Residences of Ethnic Immigrant Inflows* from Latin America to Canada, 1981-2016

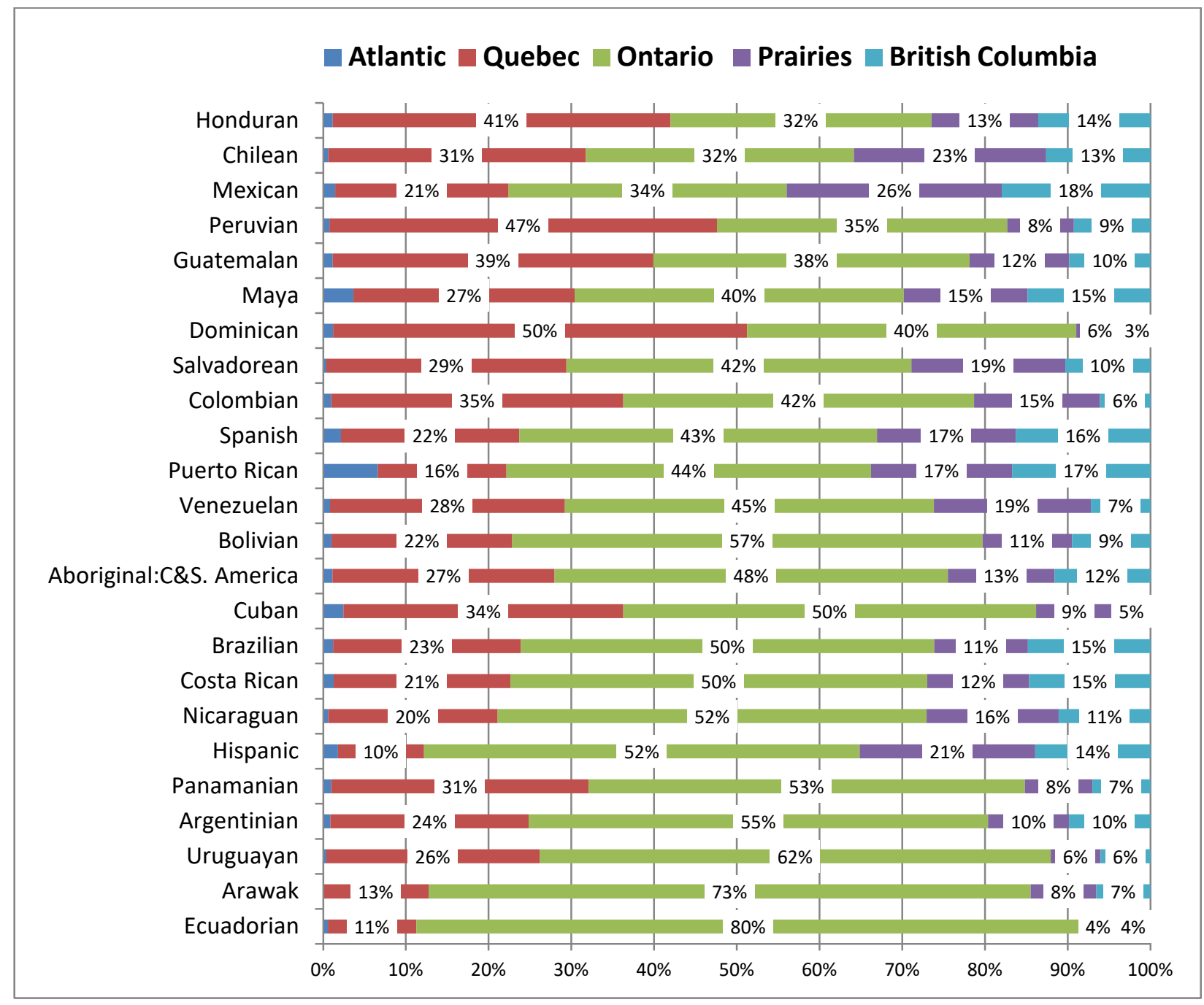

${ }^{*}$ Comprises single and multiple ethnic origins. Source: Custom Tabulation EO2695, 2016 Census of Canada

${ }^{6}$ A CMA or Central Metropolitan Area in Canada is a large population centers with at least a population of 100,000 inhabitants. 
Metropolitan Toronto constitutes the prime residential magnet for immigrants as 1 out of 4 (26\%) of Latin American inflow members resided in this city. Other major residential destinations included Montreal, Vancouver, Calgary and Edmonton CMAs (24\%, 7\%, 5\%,4\% respectively). The larger provincial concentrations around Ontario were specially observed for those reporting Ecuadorian, Arawak, Uruguayan, Argentinian and Panamanian ancestries. The larger concentrations in the French speaking province of Quebec corresponded to the Peruvian, Honduran and Guatemalan ancestry groups. About $17 \%$ of Puerto Ricans and $16 \%$ of immigrants reporting Spanish ancestries congregated in the province of British Columbia. In terms of residential preferences, the case of immigrants reporting Paraguayan and Mexican ancestries are worthy of notice. More than half of Paraguayans (57\%) and more than one out of four Mexicans (26\%) resided in the Prairie provinces of Manitoba, Saskatchewan and/or Alberta in 2016. As an offshoot of the "Lead" wave started in the 1950s, this residential preference has been linked to the movement of European families as a consequence of family reunification and the expansion of the Mennonite and other Protestant faiths in Paraguay, Bolivia and Mexico (Ogelsby, 1976; Neufeld, 2009; Kehler, 2019).

\section{Exploration 3: Admission Class Mix}

The third exploration looked at the admission class mix of ethnic inflows as this is particularly important in terms of immigrant selection, access to social services in the critical early stages of economic integration and human/social capital accumulation. At first glance, in terms of the admission class mix, Latin American immigration presented a fairly balanced composition in terms of the immigrant entry classes. About 39\% of the inflow members arrived in Canada under the family class, 35\% under the economic class and $26 \%$ under the refugee class. Looking in more detail at the national breakdown (see Chart 5), the census figures reveal some degree of polarization occurring in terms of class composition of inflows. While Central American inflows such as the Salvadoran, Nicaraguan, Guatemalan and Maya had a higher predominance of refugee entrants (50\% or more), in others we observed a higher predominance of either economic class admissions (e.g. Venezuelan, Argentinian and Brazilians) or family class entrants (e.g. Ecuadorians, Cuban or Puerto Ricans). More than half of the larger Spanish ancestry group reported being admitted as economic class immigrants, $31 \%$ as family class and $16 \%$ as refugees. The breakdown for the Colombian ancestry group revealed that close to half $(48 \%)$ were admitted as refugees, $36 \%$ as economic class and $16 \%$ as family class. With regards to the Mexican ancestry, the most frequent type of admission was as economic class (42\%) closely followed by family (41\%) and refugee class (18\%). The refugee class admission mix closely mirrored the history of migratory waves and the pressure points of push-pull forces determining population movements from the region. 
Chart 6: Admission Class Mix of Ethnic Immigrant Inflows* from Latin America to Canada, 1981-2016

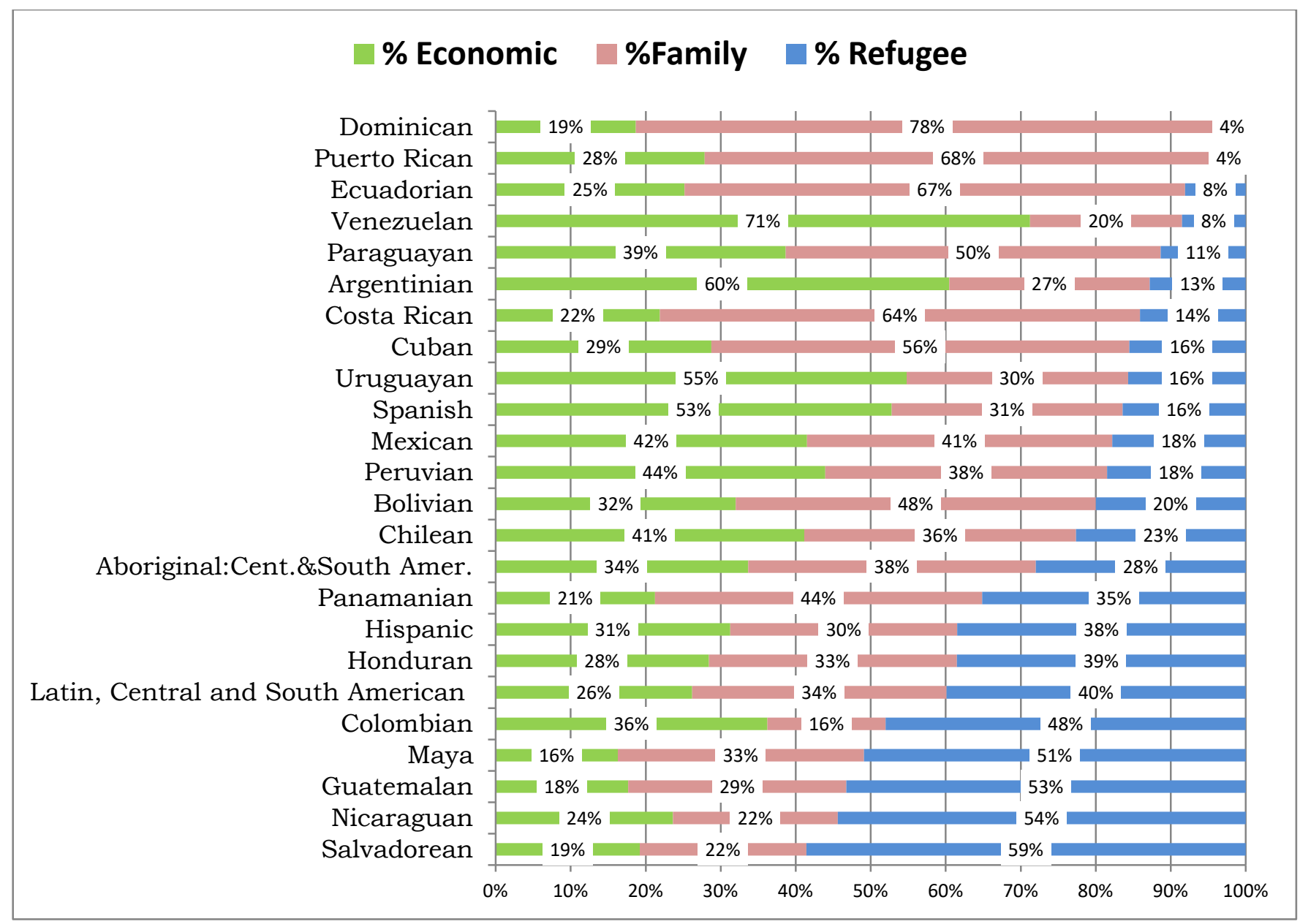

*Comprises single and multiple ethnic origins. Source: Custom Tabulations EO2695, 2016 Census of Canada

\section{Exploration 4: Population Configurations}

The fourth exploration paid attention to the population configurations characterizing the ethnic inflows. Modified population pyramids (MPPs) were used as analytical tools to carry out this exploration. The admission class was added as an extra dimension to the typical age and gender breakdown was added to detect the admission class "backbones" present in the population configurations. In contrast to the native born populations, the MPPs of immigrant populations have a "diamond" like" shape due to large proportions of individuals present in their core working age groups (e.g. 25-54). For each selected ethnic inflow, MPPs were computed for 15 5-year category age groups and charted into individual pyramids. 
Chart 7: MPP displaying age-birth cohorts, gender and immigrant admission class at entry: Colombian Ethnic Immigrant Inflow 1981-2016, Canada 2016*.

$70+$ / 1941 or before

65-69 / 1946-1950

60-64 / 1951-1955

55-59 / 1956-1960

50-54 / 1961-1965

45-49 / 1966-1970

40-44 / 1971-1975

35-39 / 1976-1980

30-34 / 1981-1985

25-29 / 1986-1990

20-24 / 1991-1995

$15-19 / 1996-2000$

10-14 / 2001-2005

$5-9$ / 2006-2010

$0-4 / 2011-2016$

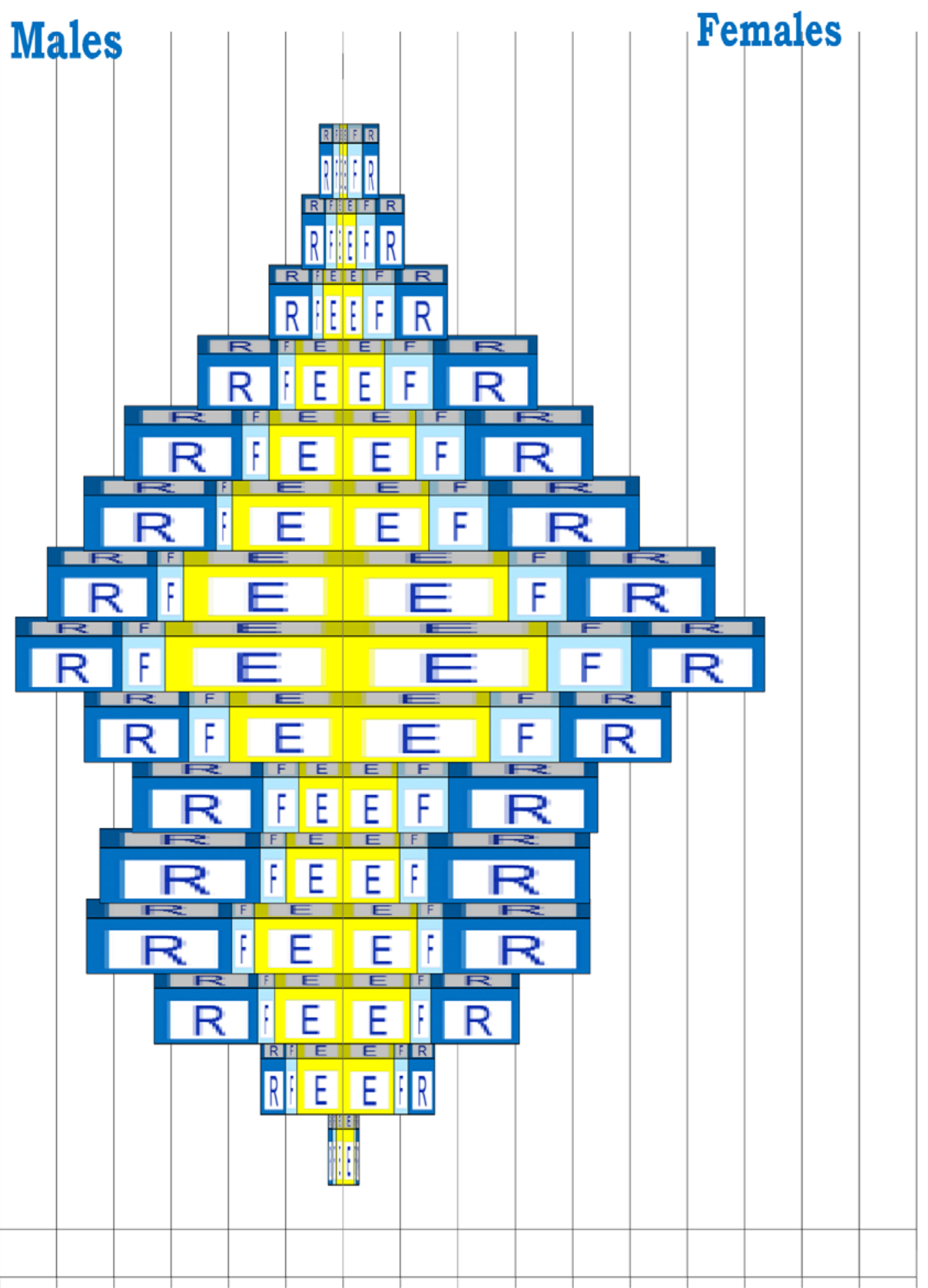

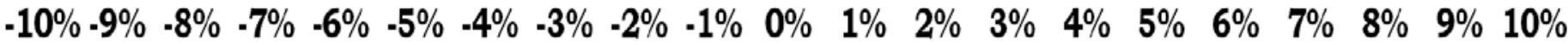


Chart 8: MPP displaying age-birth cohorts, gender and immigrant admission class at entry: Mexican Ethnic Immigrant Inflow 1981-2016, Canada 2016*.

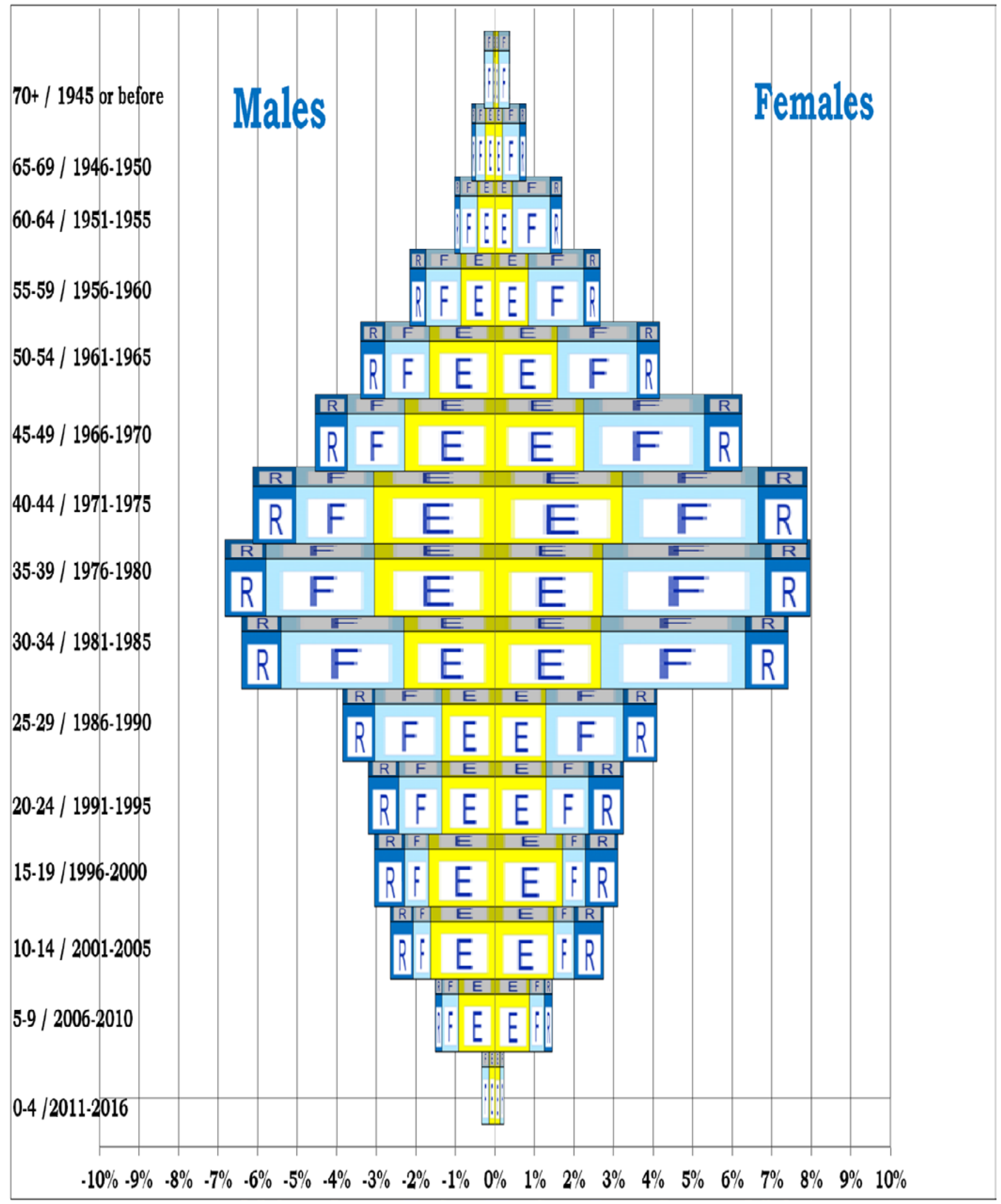

Source: Custom tabulation EO2695, 2016 Census of Canada. Symbols: E=Economic Class, F=Family Class, R=Refugee Class 
Chart 9: MPP displaying age-birth cohorts, gender and immigrant admission class at entry: Salvadoran Ethnic Immigrant Inflow 1981-2016, Canada 2016*.

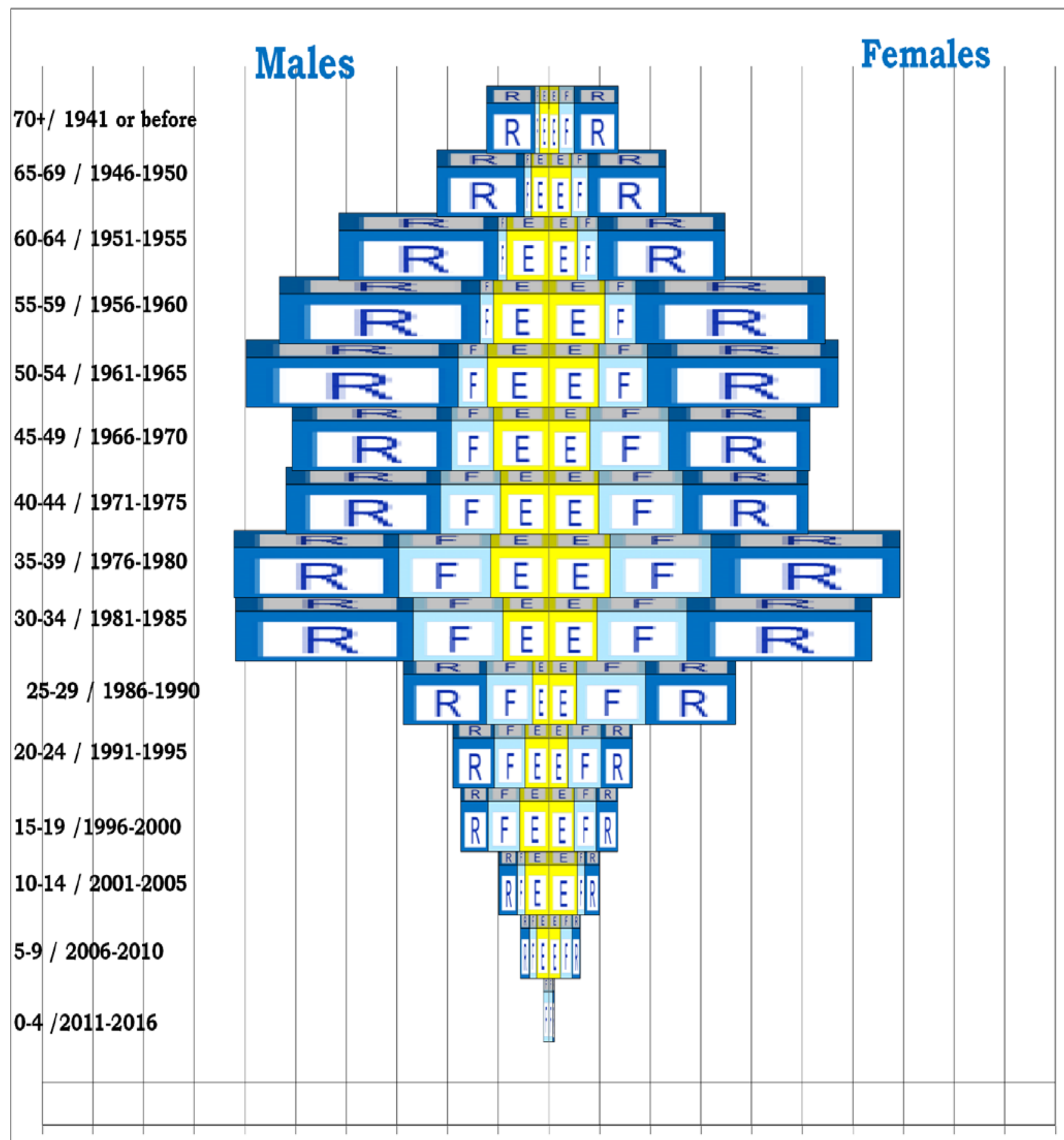

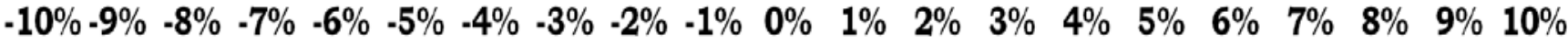


The pyramids for the three largest national ethnic inflows (Colombian, Mexican and Salvadoran) are presented in charts 7-9. The admission class composition of age-gender cohorts are symbolized by the letters $\mathrm{E}, \mathrm{F}$ and $\mathrm{R}$ which represented the three admission classes. The Colombian MPP showed a mixed admission class "backbone" where the average age was relatively younger (36.1 years old) and also displayed a preponderance of females in its midst (sex ratio=86 males per 100 females). While economic class entrants were more numerous in the 35-39 age cohort, the number of refugee entrants was particularly visible in the younger cohorts 15-19 and 20-24 (66\% each). Like the Colombian MPP, the Mexican MPP was significantly "bulged" in the middle of the pyramid but mostly consisted of economic and family class entrants. This inflow had an average age comparable to the Colombian MPP (36.6 years old) as well sex ratio (88 males per 100 males), The Salvadoran MPP displayed a strong refugee "backbone" and presented a double "bulge" in both younger and older cohorts. Refugees were particularly prevalent among those located in the 50-59 and 30-39 age cohorts where more than 57\% of their members entered as refugee class to Canada. In 2016, the average age of members of the Salvadoran ethnic inflow was 43.8 years (the oldest of the four MPPs) and displayed an almost similar number of males and females in its midst (99 males per 100 females).

\section{Exploration 5: Human Capital Attainment Profiles}

The last exploration focused on the human capital attainment profiles of ethnic inflow members of the employed working population ${ }^{7}$. Chart 8 , for instance, displays the percentage of workers aged 25-54 earning employment income in 2015 who had attained university education (bachelor's degree or higher) for selected ethnic immigrant inflows arriving to Canada during 1981 and 2016. Workers reporting Colombian and/or Venezuelan ethnic ancestries ranked among the most highly university educated workers $(50 \%+)$, following closely Egyptian, Jewish and Iranian workers.

Significant differences in university education attainment, however, were found when the immigrant categories of admission and the various national ethnic origins are taken into account. Table 1 displays the average educational levels attained by the largest ethnic ancestry groups such as the Spanish, Colombian, Mexican, Salvadoran and Peruvian groups. Census figures here suggest that, with exception of the Salvadoran inflow and for both genders, the level of university education was mostly the norm among economic class admissions of ethnic inflows. Only one in four $(24 \%)$ of Salvadoran male workers had a university level of education. Half $(57 \%)$ of Salvadoran female workers admitted under the family class reported having a high school level education or less. The lower educational level of workers of Salvadoran ancestry was previously

\footnotetext{
7 The concept of human capital attainments comprises all human outputs closely linked to workers' investments in knowledge, skills, education, and abilities (Becker, 1993; Youndt et al., 2004.). Educational and income related attainments are important indicators of the worker's position in the labour market and in the wider social ladder.
} 
noted in Mata's (1985) and Garay's (2000) work related to the fourth immigrant wave arriving in Canada in the early and mid-1980s.

Chart 10: Percentage Workers with University Education (bachelor or above bachelor level)*, Selected Ethnic Inflows to Canada 1981-2016

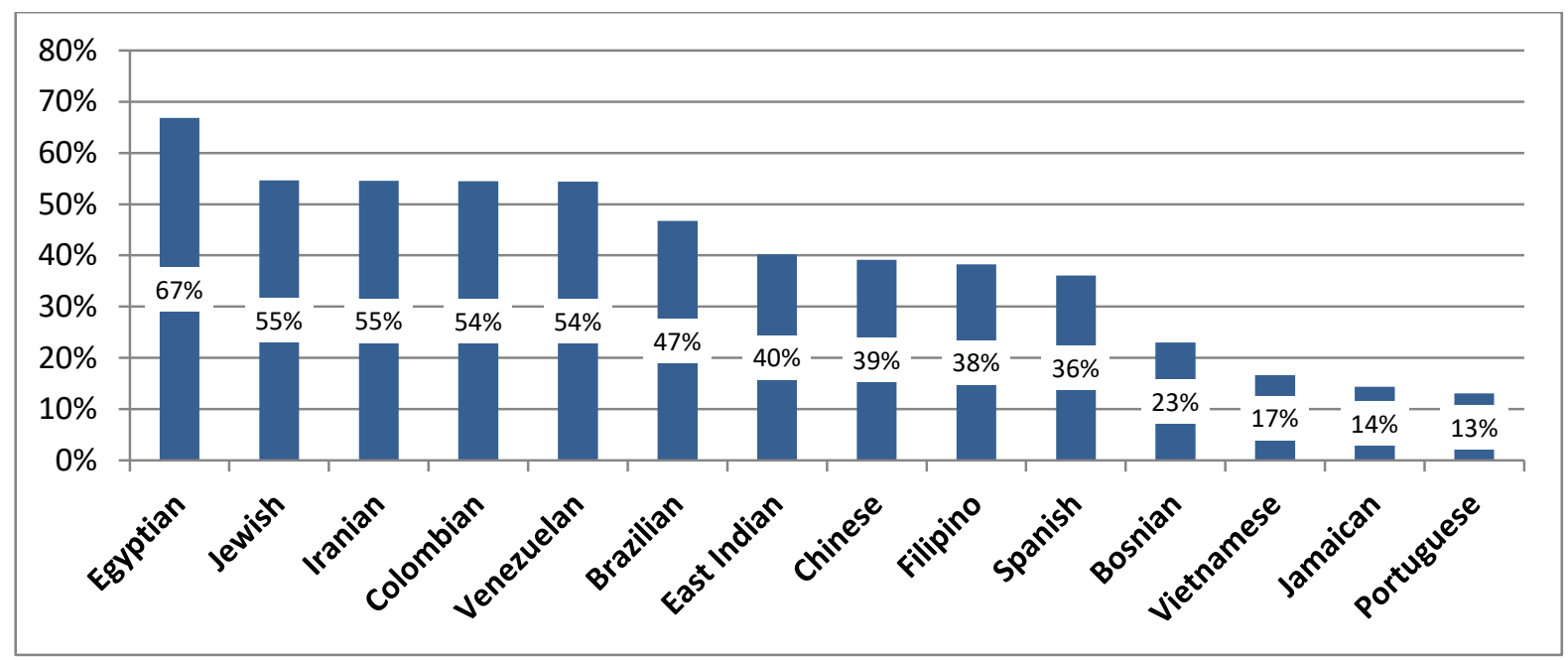

*-Population aged 25-54 with some employment income in 2015. Comprises single and multiple ethnic origins. Source: Custom Tabulation E2860, 2016 Census of Canada

Charts 11 and 12 presents the average median employment incomes of selected Latin American inflow workers by their respective genders and admission classes. For male workers, there is an observable income gap between economic class entrants and family and/or refugee class entrants ${ }^{8}$. Median incomes for economic class male labour force members reporting Venezuelan, Mexican and Colombian ancestries were found among the highest for the 25 Latin American ethnic inflows examined (around CAD54 thousand or higher). Workers from the refugee class approached those of the economic class in the case of groups such as the Salvadoran, Chilean, Nicaraguan, Guatemalan, Honduran and Cuban. Among male workers, those of the family class were located at bottom levels particularly those members of the Coup and the Central American waves arriving to Canada during the 1970s and 1980s. In the case of female workers with Latin American ancestries, which were located at substantially lower levels compared to their male counterparts, incomes were more "packed" and less visible.

\footnotetext{
${ }^{8}$ Regardless of their reported Latin American ethnic ancestries, males and females who entered Canada as economic classes tend to be concentrated in the business, professional and science related employment fields while refugee classes tend to be concentrated in manual types of occupations (trades, resources and manufacturing). More than 60\% of males aged 25-64 who reported employment income and reported Spanish, Salvadoran, Mexican or Colombian ancestries were engaged in these types of occupations in 2015 .
} 
Table 1: Highest Level of Education Attained* Ethnic Inflows from Latin America to Canada 1981-2016

\begin{tabular}{|c|c|c|c|c|c|}
\hline Gender/ Class & Total & $\begin{array}{r}\text { High } \\
\text { School or } \\
\text { Less }\end{array}$ & Trades & $\begin{array}{r}\text { Non } \\
\text { University }\end{array}$ & University \\
\hline \multicolumn{6}{|l|}{ MALES } \\
\hline \multicolumn{6}{|l|}{ Economic Class } \\
\hline Spanish & $100 \%$ & $16 \%$ & $7 \%$ & $23 \%$ & $53 \%$ \\
\hline Colombian & $100 \%$ & $13 \%$ & $4 \%$ & $20 \%$ & $63 \%$ \\
\hline Mexican & $100 \%$ & $30 \%$ & $5 \%$ & $14 \%$ & $51 \%$ \\
\hline Salvadoran & $100 \%$ & $45 \%$ & $15 \%$ & $15 \%$ & $24 \%$ \\
\hline $\begin{array}{l}\text { Peruvian } \\
\text { Family Class }\end{array}$ & $100 \%$ & $16 \%$ & $6 \%$ & $21 \%$ & $56 \%$ \\
\hline Spanish & $100 \%$ & $34 \%$ & $13 \%$ & $26 \%$ & $27 \%$ \\
\hline Colombian & $100 \%$ & $43 \%$ & $10 \%$ & $22 \%$ & $25 \%$ \\
\hline Mexican & $100 \%$ & $54 \%$ & $11 \%$ & $15 \%$ & $20 \%$ \\
\hline Salvadoran & $100 \%$ & $62 \%$ & $13 \%$ & $16 \%$ & $9 \%$ \\
\hline $\begin{array}{l}\text { Peruvian } \\
\text { Refugee Class }\end{array}$ & $100 \%$ & $36 \%$ & $17 \%$ & $26 \%$ & $21 \%$ \\
\hline Spanish & $100 \%$ & $35 \%$ & $14 \%$ & $27 \%$ & $25 \%$ \\
\hline Colombian & $100 \%$ & $38 \%$ & $10 \%$ & $25 \%$ & $28 \%$ \\
\hline Mexican & $100 \%$ & $52 \%$ & $10 \%$ & $19 \%$ & $18 \%$ \\
\hline Salvadoran & $100 \%$ & $53 \%$ & $15 \%$ & $16 \%$ & $16 \%$ \\
\hline Peruvian & $100 \%$ & $34 \%$ & $20 \%$ & $26 \%$ & $20 \%$ \\
\hline \multicolumn{6}{|l|}{ FEMALES } \\
\hline \multicolumn{6}{|l|}{ Economic Class } \\
\hline Spanish & $100 \%$ & $13 \%$ & $4 \%$ & $26 \%$ & $57 \%$ \\
\hline Colombian & $101 \%$ & $13 \%$ & $2 \%$ & $22 \%$ & $64 \%$ \\
\hline Mexican & $100 \%$ & $22 \%$ & $3 \%$ & $17 \%$ & $58 \%$ \\
\hline Salvadoran & $100 \%$ & $40 \%$ & $8 \%$ & $24 \%$ & $29 \%$ \\
\hline \multicolumn{5}{|l|}{ Family Class } & $53 \%$ \\
\hline Spanish & $100 \%$ & $25 \%$ & $6 \%$ & $30 \%$ & $38 \%$ \\
\hline Colombian & $100 \%$ & $24 \%$ & $7 \%$ & $30 \%$ & $38 \%$ \\
\hline Mexican & $100 \%$ & $33 \%$ & $6 \%$ & $26 \%$ & $35 \%$ \\
\hline Salvadoran & $100 \%$ & $57 \%$ & $11 \%$ & $19 \%$ & $13 \%$ \\
\hline $\begin{array}{l}\text { Peruvian } \\
\text { Refugee Class }\end{array}$ & $100 \%$ & $31 \%$ & $10 \%$ & $28 \%$ & $31 \%$ \\
\hline Spanish & $100 \%$ & $30 \%$ & $9 \%$ & $34 \%$ & $27 \%$ \\
\hline Colombian & $100 \%$ & $28 \%$ & $8 \%$ & $30 \%$ & $35 \%$ \\
\hline Mexican & $100 \%$ & $43 \%$ & $10 \%$ & $27 \%$ & $20 \%$ \\
\hline Salvadoran & $100 \%$ & $44 \%$ & $9 \%$ & $27 \%$ & $20 \%$ \\
\hline Peruvian & $100 \%$ & $29 \%$ & $18 \%$ & $28 \%$ & $25 \%$ \\
\hline
\end{tabular}

*Population aged 25-54 with some employment income in 2015. Comprises single and multiple ethnic origins. Source: Custom Tabulation E2860, 2016 Census of Canada 
Chart 11:Median Employment Incomes* (in thousands) of Selected Latin American Male Inflows by Admission Class, Canada 1981-2016

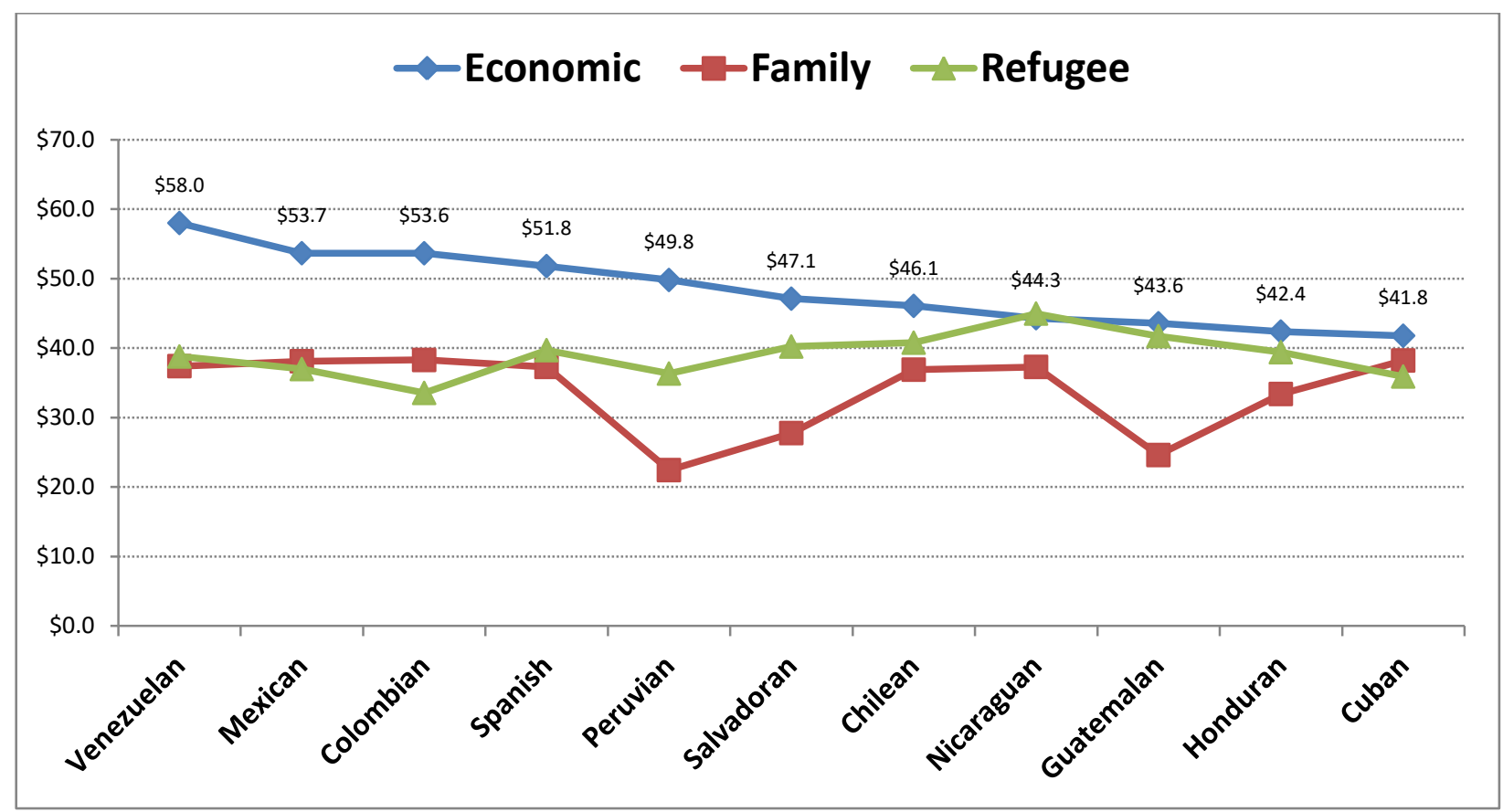

*Population aged 25-54 in the labour force reporting employment income in 2015. Comprises single and multiple ethnic origins. Source: Custom Tabulation E2860, 2016 Census of Canada

Chart 12: Median Employment Incomes* (in thousands) of Selected Latin American Female Inflows by Admission Class, Canada 1981-2016

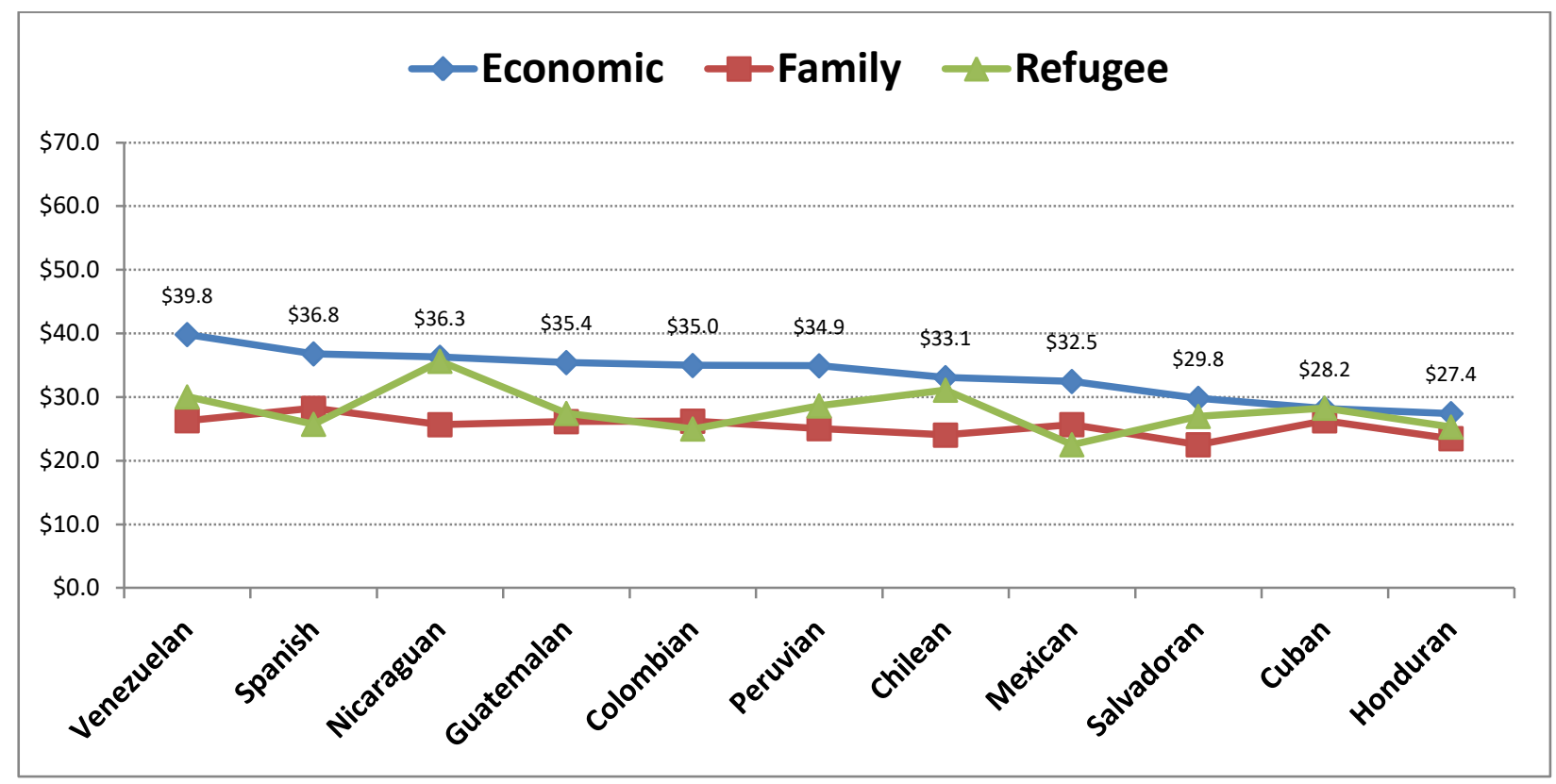

*Population aged 25-54 in the labour force reporting employment income in 2015. Comprises single and multiple ethnic origins. Source: Custom Tabulation E2860, 2016 Census of Canada 


\subsection{POST-EXPLORATIONS REFLECTIONS}

Both natural increase and the steady inflow of immigrants from various Spanish speaking regions in North, Central and South America as well as the rest of the world in the last three decades have been responsible for the exceptional growth of the "Latino" population in Canada. Data explorations on the 1981-2016 ethnic inflows carried out with the 2016 Census paints a picture of a very heterogeneous population in terms of their cultural and national backgrounds, residential preferences, admission class mix and human capital attainment profiles.

The data explorations have produced several interesting findings. One first major finding is related to the strong prevalence of the "Spanish" ethnic origin identification among most immigrants from Latin America region ${ }^{9}$. Like in the general population (including those that are Canadian born), national and other cultural identifications were found less frequently mentioned compared to Spanish. Those reporting a Spanish ancestry were an "eclectic" aggregate of individuals drawn from different parts of the continent and perhaps the world ${ }^{10}$. The strong Spanish "umbrella" type of ethnic identification suggests that immigrants have a strong bond based on similar language, culture and common history. The Spanish language and cultural heritage appears as an essential social glue that unifies individuals regardless of national boundaries.

The admission class mix of Latin American inflows to Canada varied from one inflow to another. The conditions of admission are not just administrative "entry tickets "to the host country. They constitute powerful immigrant selection mechanisms which allow the entry to Canada of individuals of different human, social and cultural capital profiles. In the case of the working age population, the conditions of admission are closely linked to access to social support and services in the critical initial stages of settlement. These conditions are responsible for a host of educational, economic and social short- and long-term outcomes for immigrants and their families. Although strong economic and family class "backbones" in most of the population were also detected in the inflows for the majority of "Latino" groups, the refugee presence was also felt. This was particularly observed among Colombian and other Central American ethnic immigrant inflows arriving in Canada over the last thirty years. Earlier waves constituted by refugee entrants are presently mutating into economic and family migratory classes and vice-versa.

Another reflection point concerns the linkages between admission class mix, ethnic community formation and generational cohorts. The explorations of the population configurations of inflows suggests that, due to immigrant selection process and passing through the life course, the resulting generational

\footnotetext{
${ }^{9}$ According to immigration statistics, immigrants from Spain accounted for less than $2 \%$ of the total volume of Latin American immigrants to Canada in the 2006-2017 period (IRCC,2018).

${ }^{10}$ It should be noted that about $55 \%$ of those reporting a Spanish ancestry were born in countries of the Latin American region while the remaining $45 \%$ in other places such as the Philippines, Spain, the U.S., U.K. and Morocco.
} 
cohorts may be quite distinct in terms of what Wertsch and Roediger (2008) call their "collective" memories. These memories consist of common experiences of immigration, historical events, cultural values and practices and anything that makes people recognize a "debt to the past". Refugees have been observed to be particularly active in social media and commemorations of major events surrounding their flight from the home country. Parents and their children may diverge and sometime clash in terms of their value orientations with respect to these memories. In Canada, this was highlighted in the work of Peddie (2012) which looked at Chilean exiles of the 1970s and their children. While the former were actively involved in community commemorations related of the 1973 Coup and dreamed for a quick political change and eventual "return to their homelands, the latter who appeared more concerned in keeping their career and educational prospects alive in their new countries. Colombians, Mexicans and other Central Americans who recently entered Canada as asylum seekers may soon be facing similar intergenerational dynamics as the Chilean exiles. In this respect, the impact of the selection process on the social psychology of the intergenerational cohorts in ethnic communities represents a relatively unexplored topic of great potential for a better understanding of the integration of Latin Americans to Canada.

A final point of reflection concerns human and social capital accumulation. The manpower brought by the five waves from the Latin American region (the fifth one in particular) have significantly benefited Canada's labour force and economy. Workers aged 25-54 and from the "fifth" technological or professional wave reporting ethnic ancestries from countries such as Colombia, Venezuela, and Brazil ranked among the most highly educated of workers who received some employment income in 2016. As the immigration plans for the next years move from projected yearly targets of permanent residents ranging from 310 to 370 thousand, with more than half being economic class admissions (IRCC, 2018), it is expected that this migratory pattern will continue rather than disappear. In terms of the family and humanitarian streams from Latin America, the prospects of migratory inflows from Latin America are expected to be somewhat stable as Canada has ratified its commitment to these policy goals particularly with respect to its assistance for those requesting asylum and protection for persecution as was done for Chileans in the 70s, the Salvadorans in the 80s and the Colombians in the 90s.

\subsection{REFERENCES}

Belanger, A. and Dumas, J. (1998). Report on the Demographic Situation of Canada:1997.Cat No 91209-XPE, Statistics Canada

Becker, G. S. 1993. Human capital: A theoretical and empirical analysis, with special reference to education (3rd ed.). Chicago: The University of Chicago Press.

Bernhard, J. Landolt, P. and Goldring, L (2009). "Transnationalizing families: Canadian immigration policy and the spatial fragmentation of care-giving among Latin American newcomers". International Migration 47, 2: 331.

Brito, E. 2019. Who We Are/ Quienes Somos. Thesis exhibition presented to OCAD University 
in partial fulfillment for the degree of Master of Design, Toronto: Toronto Media Arts Centre

Castles, S; de Hass, H and Miller, M.J. (2009). The Age of Migration, Guildford Press, New York

Carrière, Y, Martel, L, Légaré, J. and Picard, J. F. (2016). The contribution of immigration to the size and ethnocultural diversity of future cohorts of seniors, Insights on Canadian Society, Statistics, Canada, Catalogue no. 75-006-X ISSN 2291-0840

CIC (Citizenship and Immigration Canada). 2014. 2013 Facts and Figures: Overview of Permanent Residents, Ottawa

Creswell, J.W. (2007). Qualitative Inquiry and Research Design: Choosing Among Five Approaches, Sage Publications, London

ECLAC- Economic Commission for Latin America and the Caribbean (2019), Social Panorama of Latin America, 2018, (LC/PUB.2019/3-P), Santiago, 2019.CEPAL.

Elliott, S. and Yusuf, I (2014) 'Yes, we can; but together': social capital and refugee resettlement, Kōtuitui: New Zealand Journal of Social Sciences Online, 9:2, 101-110, DOI:

10.1080/1177083X.2014.951662

Hernández-Ramírez, A. (2019). Mexican Youth in Canada: A Political Economy Analysis of Motivations for Immigration, Labour Market Integration and Transnational Practices, Ph.D. thesis submitted to the Sociology Program, Carleton University, Ottawa, Ontario

Kelly, L. (2003). Bosnian Refugees in Britain: Questioning Community, Sociology, Vol 37 (1):35-49, Sage Publishing

Garay, E. (2000). Social economic and demographic profile of the Hispanic community. Toronto: Hispanic Development Council.

IRCC-Immigration, Refugees and Citizenship Canada (2017): Refugee Facts and Figures 2017, Permanent Residents by Countries of Citizenship, Ottawa, p. 21 .

IRCC-Immigration, Refugees and Citizenship Canada. (2018): 2018 Annual Report to Parliament on Immigration, Ottawa: Cat. no. Ci1E-PDF, ISSN 1706-3329, C\&I 2516-11-2018

Kehler, T. (2019). Low Mennonite Migrants' Experience Migrants' Experience of Social Exclusion and the Mediation of Social Inclusion in Southern Manitoba, paper presented to the Strangers in Their Homeland Conference, University of Manitoba, Winnipeg -Manitoba, November 2019.

Landlot, P. Bernhard, J.K, and Goldring, L. (2011) "Agenda Setting and Immigrant Politics: The Case of Latin Americans in Toronto." American Behavioral Scientist 55, no. 9 (August 2011): 1235- 1266

Mata, F. (1985). "Latin American Immigration to Canada: Some Reflections on the Immigration Statistics." Canadian Journal of Latin American and Caribbean Studies, 10, no. 20 (1985): 27-42.

Ogelsby, J.C.M (1976) Gringos From the Far North: Essays on the History of Canadian-Latin American Relations, 1866-1968, Toronto: The MacMillan of Canada, McLean-Hunter Press

Massey, D; Arango, J; Hugo, G.; Kouaouci, A.; Pellegrino, A. and Taylor, J.E. (1993). Theories of International Migration: A Review and Appraisal, Population and Development Review 19:3,p.431-466

McLeish, S. (2016). Adding Immigrant Admission Category to the Canadian Census of Population. paper presented to UNECE Work Session on Migration Statistics, May 18-20, Social and Aboriginal Statistics Division, Statistics Canada, Ottawa

Neufeld, A.(2009). The Mennonite Experience in Paraguay I - The Congregational and Theological 
Experience, The Conrad Grebel Review 27, no. 1 (Winter 2009)

Peddie, F. (2018). Young, Well Educated and Adaptable People: Chilean Exiles, Identity and Daily Life in Canada, 1973 to the Present Day, Unpublished Ph.D. Dissertation, Graduate Program in History, York University, Toronto, retrieved from https:// yorkspace.library.yorku.ca

Piche, V. (2019) Política migratoria canadiense en un contexto global. ¿El modelo es realmente "excepcional"? in "Las Nuevas Politicas Migratorias Canadienses, Governanza neoliberal y manejo de la otredad", Lara Flores, S.M; Pantaleón, J. Martin, P.M (coordinadores), UNAM, Universidad de Montreal Publication, Mexico City, p.23-54

Statistics Canada, SC ( 2017). Ethnic and cultural origins of Canadians: Portrait of a rich heritage, Census of Population 2016, Catalogue no. 98-200-X2016016 ISBN 978-0-660-20339-3

Simmons, Alan B. (1993) "Latin American Migration to Canada: New Linkages in the Hemispheric Migration and Refugee Flow System.” International Journal 48, no. 2: 282-309.

Statistics Canada (2007)."The Latin American Community in Canada.: https://www150.statcan.gc.ca/n1/pub/89-621-x/89-621-x2007008-eng.htm.

Strauss, W., and Howe, N. Generations: The History of America's Future, 1584 to 2069. New York: Morrow, 1991.

Trovato, F. (2009). Canada's Population in a Global Context: An Introduction to Social Demography. Don Mills: Oxford University Press.

Veronis, L. (2010): Immigrant Participation in the Transnational Era: Latin Americans' Experiences with Collective Organising in Toronto, Journal of International Migration and Integration 11(2):173-192

Wallbeck, O. (2002). The concept of diaspora as an analytical tool in the study of refugee communities, Journal of Ethnic and Migration Studies, Vol (28):2, 221-238

Wertsch, J.V and Roediger, H.L (2008). Collective memory: Conceptual foundations and theoretical approaches, MEMORY, 2008, 16 (3), 318326

Youndt, M. A., et al. (2004). Intellectual Capital Profiles: An Examination of Investments and Returns. Journal of Management Studies, 41(2). 335-361. 